\title{
CORRESPONDENCE
}

\section{A note on the distribution and significance of metamorphic limestones in the Moine and Lewisian of the Scottish Highlands and Islands}

SIR - Much effort has been devoted of late to dividing up the 'Moine area' - that great tract of the Highlands between the Moine/Dalradian boundary and Moine Thrust. Attempts continue northwest of the Great Glen to extend northward the Morar, Glenfinnan and Loch Eil Divisions established by Johnstone, Smith \& Harris (1969), to define the geochemical characteristics of the three divisions (Winchester, Lambert \& Holland, 1981) and to map Lewisian inliers (e.g. Harrison \& Moorhouse, 1976). Similar attempts are being made across the Great Glen to erect divisions within the Moine (e.g. Piasecki, 1980), and to distinguish lithologies geochemically from each other and from similar Dalradian (e.g. Lambert, Holland \& Winchester, 1982).

Relevant to these studies, but neglected for many years, are the numerous metamorphosed limestones which occur within the Moine area. ('Limestone' here includes all carbonate-rich metasediments, but not the much better known carbonate-poor calc-silicate ribs of the Moine succession.) According to Johnstone (1975, p. 33), limestones cropping out within the Moine area are not integral parts of the Moine succession but 'represent infolds or slices of Lewisian or Dalradian rocks'. Yet more than 50 such outcrops exist, some of which have never been described or recorded, others neglected since the early Geological Survey Memoirs; only about 10 are generally accepted as forming parts of Lewisian inliers (e.g. Glenelg, Scardroy). Even the established Lewisian limestones of the Foreland have suffered long neglect and, again, a few have never been recorded.

This is partly because published maps, and even the most comprehensive survey of Scottish limestone resources (Robertson, Simpson \& Anderson, 1949), only cover a limited selection of these limestones, several others lying within unpublished or unsurveyed one-inch sheets (e.g. 63, 72, 73, 115). This note therefore presents the first locality map (Fig. 1) of all metamorphic limestones known to the Institute northwest of the Dalradian boundary. A comprehensive bibliography, compilation maps and listings of over 100 individual outcrops are available from the author.

Ages assigned to the limestones within the Moine area are invariably inconclusive or contradictory: for example, Ardgour and others on Figure 1 have been classed as both Dalradian and Moine (cf. Drever, 1940; Bailey, 1960); Glen Urquhart and Shinness as both Moine and Lewisian (cf. Horne \& Hinxman, 1914, with Francis, 1958, 1964; Read, Phemister \& Ross, 1926 with Winchester \& Lambert, 1970); Colonsay as either Torridonian or Dalradian (Stewart, 1962, 1975).

Yet the significance of these ages could be out of all proportion to the sizes of the limestone outcrops. If only a few are integral parts of the Moine, as assumed by Francis $(1958,1964)$ and Piasecki $(1975$, 1980), current lithological understanding of the Moine needs major revision. If, on the other hand, 'Moine limestones' do not exist, then the number of Lewisian or Dalradian infolds in the Moine area must be greater than currently recognized. In particular, if either the Ardgour or Glen Dessarry limestones lie within Dalradian downfolds, as suggested by Drever (1940) and Shackleton (in discussion to Richardson, 1968), or Gleann Liath within a Lewisian slice (Mould, 1946), a radically new picture of the Great Glen, of the distribution of former Dalradian cover and of Lewisian basement, would be implied. Again, Rathbone \& Harris (1980) identified the Rosemarkie inlier (Fig. 1) as mixed Lewisian /Moine, and the adjacent Nigg inlier as exclusively Moine, but took no account of the limestones present in both inliers.

Furthermore, the limestones could help to elucidate the relationship between the Grampian and Northern Highland Moines: if the Findhorn, Grantown, Kincraig and Lochan Eilean limestones on Figure 1 prove to be of Dalradian type, this will support the incorporation of some Grampian 'Moines' into the Dalradian (Harris et al. 1978); if, however, they prove unlike Dalradian limestones and like those within the Loch Eil Division (Inverness, ?Ardgour, Glen Urquhart on Figure 1), this will support the correlation by Piasecki, Van Breemen \& Wright (1981) of the 'Grampian Division Moines' with the Loch Eil Division.

Detailed studies of all Highland limestones are therefore being made, in an attempt to decide 


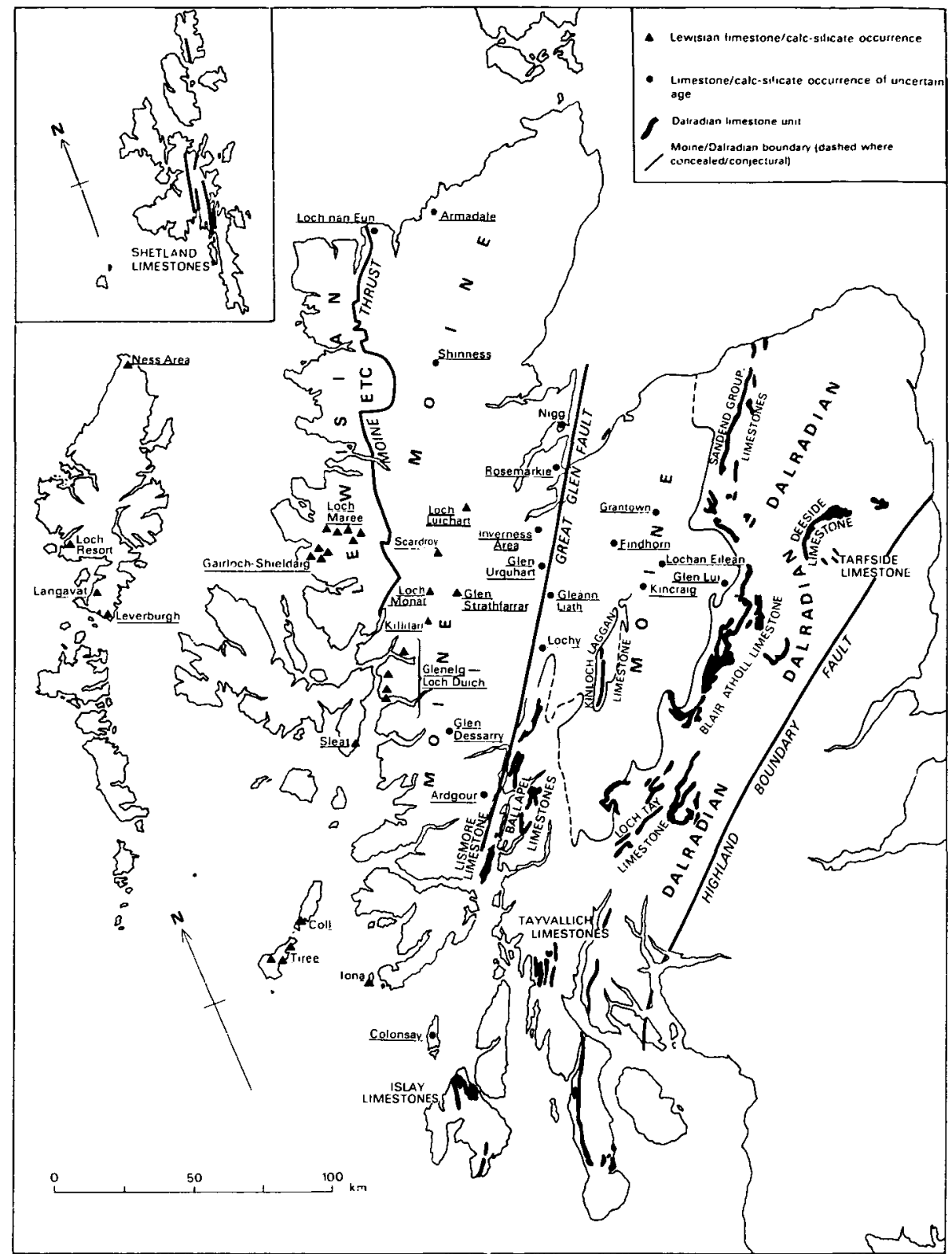

Figure 1. Distribution of metamorphic limestones in the Scottish Highlands and Islands. Major Dalradian limestone outcrops (shown for completeness only) sketched from Geological Survey 10-mile map (3rd Edition, 1979). Smaller Dalradian limestones not shown owing to space restrictions. Lewisian and unassigned limestones are only shown diagrammatically, to indicate their locations.

whether 'Moine limestones' really exist and, if not, to assign ages to those within the Moine area. Results will be reported shortly on the limestones along the Great Glen, and subsequently on the remainder.

Acknowledgements to D. J. Fettes, F. May and W. Mykura for helpful comments on the manuscript. M. S. Garson, G. S. Johnstone, F. May, J. R. Mendum and D. I. Smith provided the details for a 
number of previously undocumented limestone occurrences. This note is published by permission of the Director, Institute of Geological Sciences (N.E.R.C.).

\section{References}

Bailey, E. B. 1960. Geology of Ben Nevis and Glen Coe. Mem. geol. Surv. Scotland (sheet 60).

Drever, H. I. 1940. The geology of Ardgour, Argyllshire. Trans. R. Soc. Edinb. 60, 141-70.

Francis, G. H. 1958. Petrological studies in Glen Urquhart, Inverness-shire. Parts I \& II. Bull. Br. Mus. nat. Hist., Min. 1, 123-64.

Francis, G. H. 1964. Petrological studies in Glen Urquhart, Inverness-shire. Part III. Bull. Br. Mus. nat. Hist., Min. 1, 165-99.

Harris, A. L., Baldwin, C. T., Bradbury, H. J., Johnson, H. D., Smith, R. A. 1978. Ensialic Basin Sedimentation; the Dalradian Supergroup. In Crustal Evolution in NW Britain (ed. D. R. Bowes \& B. E. Leake). Geol. J. Spec. Issue 10, 115-38.

Harrison, V. E. \& Moorhouse, S. J. 1976. A possible early Scourian supracrustal assemblage within the Moine. J. Geol. Soc. Lond. 132, 461-6.

Horne, J. \& Hinxman, L. F. 1914. Geology of the country round Beauly and Inverness. Mem. Geol. Surv. Scotland (sheet 83).

Johnstone, G. S. 1975. The Moine Succession. In Precambrian (ed. A. L. Harris and others), pp. 40-42. Geol. Soc. Lond. Spec. Rept. 6.

Johnstone, G. S., Smith, D. I. \& Harris, A. L. 1969. The Moine Assemblage of Scotland. In North Atlantic Geology and Continental Drift (ed. M. Kay). Mem. Am. Assoc. Petrol. Geol. 12, 159-80.

Lambert, R. St J., Holland, J. G. \& Winchester, J. A. 1982. A geochemical comparison of the Dalradian Leven schists and the Grampian Division Monadhliath schists of Scotland. J. geol. Soc. Lond. 139, 71-84.

Mould, D. D. C. P. 1946. The geology of the Foyers 'granite' and the surrounding country. Geol. Mag. 83, 249-65.

Piasecki, M. A. J. 1975. Tectonic and metamorphic history of the Upper Findhorn, Inverness-shire. Scott. J. Geol. 11, 87-116.

Piasecki, M. A. J. 1980. New light on the Moine rocks of the Central Highlands of Scotland. J. geol. Soc. Lond. 137, 41-59.

Piasecki, M. A. J., Van Breemen, O. \& Wright, A. E. 1981. Late precambrian geology of Scotland, England \& Wales. In Geology of the North Atlantic Borderlands. Mem. Can. Assoc. Petrol. Geol. $7,57-94$.

Rathbone, P. A. \& Harris, A. L. 1980. Moine and Lewisian near the Great Glen Fault in Easter Ross. Scott. J. Geol. 16, 51-64.

Read, H. H., Phemister, J. \& Ross, G. 1926. Geology of Strath Oykell and lower Loch Shin. Mem. geol. Surv. Scotland (sheet 102).

Richardson, S. W. 1968. The petrology of the metamorphosed syenite in Glen Dessarry, Invernessshire. Q. Jl. geol. Soc. Lond. 124, 9-52.

Robertson, T., Simpson, J. B. \& Anderson, J. G. C. 1949. The Limestones of Scotland. Mem. geol. Surv. Spec. Rept. Min. Res. 35.

Stewart, A. D. 1962. On the Torridonian sediments of Colonsay and their relationship to the main outcrop in north-west Scotland. Geol. J. 3, 121-55.

Stewart, A. D. 1975. 'Torridonian' rocks of western Scotland. In Precambrian (ed. A. L. Harris and others), pp. 43-51. Geol. Soc. Lond. Spec. Rept. 6.

Winchester, J. A. \& Lambert, J. 1970. Geochemical distinctions between the Lewisian of Cassley, Durcha \& Loch Shin, and the surrounding Moines. Proc. Geol. Ass. 81, 275-301.

Winchester, J. A., Lambert, R. St J. \& Holland, J. G. 1981. Geochemistry of the western part of the Moine assemblage. Scott. J. Geol. 17, 281-94.

Institute of Geological Sciences

West Mains Road

Edinburgh EH9 3LA

Scotland

14 April 1983 